Fikrah: Jurnal Ilmu Aqidah dan Studi Keagamaan

ISSN 2354-6147 EISSN 2476-9649

Tersedia online di: journal.stainkudus.ac.id/index.php/fikrah

DOI: 10.21043/fikrah.v6i2.4081

\title{
Apakah Beragama Membuat Bahagia? Meta-Analisis
}

\author{
M. Nur Ghufron \\ Institut Agama Islam Negeri, Kudus, Indonesia \\ emnurghufron78@@email.com
}

\section{Rini Risnawita Suminta}

Institut Agama Islam Negeri, Kediri, Indonesia

rinirisnawita16@email.com

\begin{abstract}
Abstrak
Artikel ini adalah meta-analisis mengenai hubungan antara agama dan kebahagiaan. Meta-analisis bertujuan untuk menyimpulkan, mengintegrasikan dan menginterpretasikan data dari riset terdahulu. Oleh karena itu, karena sangat tergantung pada riset utama. Data yang dianalisis melalui metode ini harus memiliki konstruk yang sama dan dengan pola korelasi sehingga dapat dibandingkan satu dengan lainya. Artikel ini dilakukan secara kuantitatif dengan mereview 15 penelitian dari 9 artikel dengan sampel gabungan berjumlah 7272. Analisis yang dilakukan dalam artikel ini berupa mengoreksi kesalahan sampling dan kesalahan pengukuran. Hasil analisis menunjukkan bahwa agama memiliki korelasi dengan kebahagiaan. Hasil penelitian menunjukkan bahwa agama dapat menjadi prediktor kebahagiaan.
\end{abstract}

Kata kunci: Agama, kebahagiaan, meta-analisis 


\begin{abstract}
This Study was meta-analysis of the correlation between religion and happiness. Metaanalysis aims at concluding, integrating, and interpreting data gathered from previous research. Therefore, apart from acting as primary research, the data to be analyzed through this method must have the same constructs and correlation patterns so that it could be compared with one another. The quantitative review includes 15 studies from 9 articles that contained a combined sample of approximately 7272 . This analysis extends previous work by directly correcting error of sampling and measurements. Summary analysis provided support that religion has a correlation on happiness. The result showed religion have been identified as predictors and happiness.
\end{abstract}

Keywords: religion, happiness, meta- analysis

\title{
Pendahuluan
}

The purpose of our lives is to be happy (Malpere, 2010) menjelaskan bahwa sumber kebahagiaan telah lama dicari. Bahkan sebagaimana ungkapan yang dikatakan Dalai lama (Malpere, 2010) bahwa tujuan hidup adalah mencari kebahagiaan. Jawabannya berkisar dari keberuntungan dan ketenaran sampai adanya semua harta material yang melimpah. Studi tentang kebahagiaan dan asal-usulnya terus dilakukan. Agama dan spiritualitas telah disebut-sebut selama berabad-abad sebagai jalan menuju kebahagiaan. Psikolog tertarik untuk mengungkap pada apa yang berkontribusi pada kebahagiaan seseorang, dan diantaranya adalah faktor agama.

Barkan dan Greenwood (2003) berpendapat, meskipun banyak penelitian meneliti agama dan kebahagiaan, penjelasan teoretisnya masih belum jelas. Beberapa penelitian berpendapat bahwa keterlibatan agama meningkatkan hubungan seseorang dengan Tuhan, yang kemudian meningkatkan tingkat kebahagiaan seseorang. Penelitian lain menunjukkan bahwa keterlibatan agama meningkatkan jumlah dan kualitas hubungan sosial seseorang dalam komunitas (Ellison \& George, 1994), yang kemudian meningkatkan tingkat kebahagiaan seseorang (Diener \& M.E.P, 2002). Faktor yang rumit dalam analisis ini adalah masalah urutan kausal. Mana yang lebih dulu, kehadiran agama atau kebahagiaan? Para ahli agama lebih mengutamakan kehadiran keagamaan sebagai variabel independen (Barkan \& Greenwood, 2003), menunjukkan bahwa tingkat kehadiran keagamaan yang dilaporkan lebih tinggi menyebabkan tingkat kebahagiaan dan kesejahteraan yang dilaporkan lebih tinggi. Pada beberapa penelitian 
juga diungkap bagaimana hubungan antara agama dengan kebahagiaan juga sangat signifikan (Wahyuningsih, 2008); (M. S. Utami, 2012); (Masse, 2016); (Shaeful RS, 2011); (T. N. Utami \& Nuraini, 2016).

Hubungan antara agama dengan kebahagiaan telah dipelajari dan diterbitkan dalam beberapa jurnal ilmiah. Penulis menerapkan meta-analisis terhadap pola hubungan antara kedua variabel dari 15 penelitian dan 9 artikel, baik hasil dari jurnal ilmiah yang diterbitkan atau tesis/disertasi yang dipublikasikan melalui internet dari 2010 sampai tahun 2016. Tujuannya adalah untuk melihat apakah variabel agama, jika diringkas menjadi satu, akan menampilkan konsistensi dan dapat digunakan sebagai dasar untuk menjawab pertanyaan apakah agama dapat menentukan kebahagiaan.

\section{Religiusitas}

Religiusitas secara definisi mempunyai konsep yang luas dan sulit untuk direfleksikan. Secara etimologis antara "religiusitas" dan "agama" sangat erat kaitannya. Namanya berasal dari bahasa Latin, religio atau religare yang sama, yang berarti mengumpulkan atau mengikat (Kahmad, 2002). Kata agama (bahasa Indonesia) menurut Ali (Ali \& Muhdho, 1996) sama dengan "diin" (dari bahasa Arab) juga sama dengan bahasa yang ada di Eropa seperti disebut" the religie" (Belanda), "die religion", (Bahasa Jerman) "religi", religion (bahasa Inggris) dan "la religion" (Perancis) (Abercrombie, N., Hill, S. Turner, 2006). Dalam bahasa Semit kata "diin" berarti hukum (hukum), sedangkan dalam bahasa Arab, kata "diin" berarti menguasai, menundukkan, patuh, utang, pembalasan, kebiasaan (Ali \& Muhdho, 1996).

Anshori (Ghufron \& Risnawati, 2010) membedakan antara istilah agama atau religi dan religiusitas. Jika agama mengacu pada aspek formal yang berkaitan dengan aturan dan kewajiban, maka religiositas mengacu pada aspek agama yang telah dijalani seseorang di dalam hati. Religiusitas sebagai agama karena internalisasi agama menjadi bersifat pribadi. Faiver, Ingersoll, O'Brien \& McNally (Faiver, Ingersoll, O'Brien, \& McNally, 2001) menghubungkan spiritualitas dan agama dengan menyatakan bahwa agama adalah praktik yang dilalui individu dalam menyalurkan spiritualitas. Sementara religiusitas menurut Mattis dan Jagers (Mattis \& Jagers, 2001) sebagai tingkat kepatuhan seseorang terhadap keyakinan, doktrin, dan praktik agama. Reitsma, Scheepers \& 
Janssen (2007) mendefinisikan religiusitas sebagai praktik, keyakinan, pengalaman, dan konsekuensi.

\section{Kebahagiaan}

Menurut Diener, Lucas, dan Oishi (Diener, Lucas, \& Oishi, 2005) kebahagiaan merupakan konsep yang luas, seperti adanya emosi yang positif atau pengalaman yang menyenangkan, rendahnya mood yang negatif, dan memiliki kepuasan hidup yang tinggi. Seseorang dikatakan mengalami kebahagiaan yang tinggi jika mereka sudah merasakan puas dengan kondisi hidup mereka, sering merasakan emosi positif dan jarang merasakan emosi negatif. Sementara menurut Eddington \& Shuman (Eddington \& Shuman, 2008) kebahagiaan juga dapat timbul karena adanya keberhasilan individu dalam mencapai apa yang menjadi keinginan hatinya, dan dapat mengolah kekuatan dan keutamaan yang dimiliki dalam kehidupan sehari-hari, serta dapat merasakan sebuah keadaan yang menyenangkan.

Menurut Veenhoven (Veenhoven, 2009) kata kebahagiaan memiliki kesamaan arti dengan hidup yang berkualitas dan kesejahteraan. Makna di atas mewakili arti hidup yang baik, tetapi belum spesifik apakah yang baik mengenai hidup itu. Veenhoven memaparkan bahwa ada empat kelompok penjelasan tentang kebahagiaan dengan terminologi berbeda, yaitu: Pertama, livability of environment atau kemampuan hidup sesuai dengan lingkungan. Kadang-kadang hidup yang berkualitas (quality of life) dan kesejahteraan (well-being) digunakan untuk arti kebahagiaan, khususnya dalam tulisan para sosiolog dan ahli ekologi. Para ahli ekonomi biasanya menggunakan kata kesejahteraan untuk menggambarkan kebahagiaan (welfare). Kedua, life-ability of a person atau kemampuan hidup seseorang. Ketiga, utility of life atau keberfungsian dalam hidup. Bahwa hidup yang baik itu haruslah lebih baik untuk hal tertentu. Hal ini menjadi sesuatu yang diyakini bernilai lebih tinggi, seperti memperbaiki ekologi atau pengembangan kebudayaan. Hidup yang berguna ini biasanya disamakan juga dengan kebahagiaan. Keempat, satisfaction with life atau kepuasan terhadap hidup. Hal ini berhubungan dengan kesadaran manusia akan apresiasinya terhadap hidup yang berkualitas. Secara umum terminologi ini lebih mengacu pada kesejahteraan subyektif (subjective well-being), kepuasan hidup (life-satisfaction), dan juga kebahagiaan (happiness). 
Menurut Gabrielle (2008) ada tiga pendekatan pada kebahagiaan yaitu: Pertama, hedonism atau hedonisme; seringkali dipandang sebagai kepuasan maksimal dan menghindari rasa sakit, atau berfokus pada pencapaian kepuasan akan satu hal tertentu yang diinginkan (Peterson, Park, \& Seligman, 2005). Kedua, meaning atau makna; adalah perasaan yang dialami oleh seseorang yang muncul ketika dirinya terlibat dalam sebuah kegiatan yang diyakni dapat memberikan kepuasan dan makna ke dalam kehidupannya. Ketiga, engagement atau keterikatan pada pekerjaan; adanya keseimbangan antara keahlian dan tantangan dan ketika aktivitas itu menjadi sebuah keyakinan maka secara alamiah akan dikerjakan dengan sukarela tanpa adanya paksaan.

Beberapa definisi di atas memiliki benang merah, yaitu kebahagiaan adalah perasaan dan pengalaman menyenangkan yang memberi makna dalam hidup, sehingga memberikan kemampuan untuk menerima keadaan kerja dan lebih produktif di tempat kerja yang dapat dimaknai sebagai kepuasan hidup dan memberi kebahagiaan bagi pribadi tersebut.

\section{Hubungan antara Agama dengan kebahagiaan}

Beberapa penelitian telah menunjukkan bahwa agama memainkan peran penting dalam meraih kebahagiaan seseorang. Misalnya, French dan Joseph (French \& Joseph, 1999) menguji hubungan antara religiusitas dan kebahagiaan. Penelitiannya melibatkan 101 mahasiswa sarjana penuh waktu di mana 57 adalah laki-laki dan 44 perempuan. Usia mereka berkisar antara 18 hingga 49 tahun dengan usia rata-rata 21 tahun. Para peserta menyelesaikan 5 pengukuran yang meliputi Skala sikap Francis terhadap kekristenan, skala depresi-kebahagiaan, Oxford Inventori Kebahagiaan, tes tujuan kehidupan dan Indeks aktualisasi diri. Hasil penelitiannya menemukan bahwa tidak peduli apa ukuran yang mereka gunakan, orang-orang religius mendapat nilai lebih tinggi pada kebahagiaan. Skor yang lebih tinggi pada skala sikap Francis menuju kekristenan ditemukan terkait dengan skor yang lebih tinggi pada skala depresikebahagiaan dan Oxford inventori kebahagiaan serta tujuan dalam tes kehidupan dan indeks aktualisasi diri.

Sappington dan Baker (Sappington \& Baker, 1995) percaya bahwa agama akan dapat meningkatkan prediksi altruisme dengan memeriksa keyakinan berdasarkan 
kecerdasan dan emosi seseorang. Khususnya dengan mengukur bobot yang diberikan oleh agama untuk membantu orang yang membutuhkan. Penelitian mereka terdiri dari 71 mahasiswa sarjana yang 45 orang Katolik/Ortodoks, 11 orang non-Kristen dan 7 non-religius. Para peserta mengisi formulir kegiatan sukarela dan formulir kegiatan keagamaan. Sappington dan Baker mampu mendukung prediksi mereka bahwa semakin banyak bobot yang diberikan pada agama untuk membantu mereka yang membutuhkan, semakin mungkin seseorang mampu memprediksi tindakannya.

Argyle dan Hills (2000) melakukan penelitian yang mencakup pemeriksaan pengalaman mistik dan kebahagiaan. Penelitiannya melibatkan 364 orang dewasa, dimana 46\% adalah anggota gereja. Ada 127 pria dan 237 wanita yang berusia antara 1883 tahun dengan usia rata-rata 41 tahun. Para peserta menyelesaikan pengukuran tentang kebahagiaan, pengukuran yang dirancang untuk mengevaluasi pengalaman mistis-religius, dan pengukuran untuk variabel kepribadian kognitif dan lainnya. Pengukuran termasuk skala 25 item termasuk beberapa dari Hoods Mystical Experience Scale, Oxford Happiness Inventory, Eysenck Personality Questionnaire, Preferensi untuk Skala Kesendirian, Skala Harga Diri Rosenberg, Skala Tendensi Empathic, Tes Orientasi Kehidupan, Index Kehidupan dan Formulir Penelitian Kepribadian Jackson. Hasil penelitian menunjukkan bahwa, kebahagiaan yang lebih tinggi tidak berkaitan dengan pengalaman anggota gereja. Namun, mereka mampu menunjukkan korelasi yang sederhana namun signifikan antara kebahagiaan dan pengaruh agama secara keseluruhan.

Barkan dan Greenwood (2003) menyatakan bahwa orang yang menghadiri layanan keagamaan lebih mungkin melaporkan tingkat kebahagiaan yang lebih tinggi. Sementara Miller dan Thoresen (2003) menunjukkan, agama sering dicirikan oleh tujuan dan keprihatinan non-spiritual lainnya seperti politik ekonomi budaya dan sosial. Steger dan Frazier (2005) melakukan dua penelitian untuk menguji bahwa makna hidup berhubungan dengan agama dan kesehatan psikologis. Ada 512 peserta dari Universitas Midwestern dengan usia rata-rata 20 tahun. Hasil penelitian menemukan bahwa peserta yang terlibat dalam kegiatan keagamaan percaya bahwa hidupnya bermakna dan memuaskan. Pada penelitian kedua melibatkan 84 peserta dari kelas pengantar psikologi pengantar dengan usia rata-rata peserta berusia 20 tahun. 
Hasil penelitian menemukan korelasi kuat antara aktivitas keagamaan sehari-hari dan kesejahteraan yang menyarankan bahwa para peserta dapat mencapai perasaan kesejahteraan yang lebih besar yang secara langsung berasal dari makna kehidupan yang diilhami oleh agama mereka.

Peterson, Park \& Seligman (Peterson et al., 2005) mempelajari berbagai orientasi untuk mencapai kebahagiaan dan hubungannya dengan kepuasan hidup. Ada 845 peserta dewasa yang menanggapi survey tersebut. Kepuasan hidup diukur dengan tiga cara berbeda; melalui kesenangan, melalui keterlibatan dan melalui makna. Hasil penelitian menunjukkan bahwa orang-orang yang mendapat skor rendah pada ketiga pengukuran melaporkan kepuasan hidup yang rendah serta orang yang mendapat skor tinggi pada ketiga pengukuran melaporkan kepuasan hidup yang lebih tinggi. Lebih lanjut, mereka yang mendapat nilai tinggi pada ketiga orientasi secara bersamaan melaporkan bahwa kepuasan hidup terbesar. Oleh karena itu, penelitian menunjukkan bahwa orientasi ini harus dikejar secara bersamaan untuk mencapai kepuasan hidup.

Abdel-Khalek (Abdel \& Ahmed, 2006) meneliti hubungan antara, dan perbedaan gender dalam, kebahagiaan, kesehatan fisik, kesehatan mental dan religiusitas. Penelitiannya melibatkan 2210 sukarelawan sarjana Muslim Kuwait, yang 1056 adalah laki-laki dan 1154 perempuan dan usia rata-rata adalah 20 tahun. Para peserta menyelesaikan empat skala penilaian mandiri. Hasil penelitian menemukan bahwa kesehatan mental menyumbang $60 \%$ dari varians dalam memprediksi kebahagiaan, sementara religiusitas menyumbang sekitar 15\% dari varians dalam memprediksi kebahagiaan. Hasil penelitian ini tidak menemukan bahwa kesehatan fisik berkontribusi terhadap kebahagiaan, tetapi menemukan orang-orang religius lebih bahagia.

Tkach dan Lyubomirsky (2006) menguji aktivitas yang dilakukan untuk mempertahankan atau meningkatkan kebahagiaan. Penelitiannya melibatkan 500 mahasiswa yang berbeda secara etnis di mana 341 adalah perempuan, 157 laki-laki dan 2 tidak diketahui. Hasil penelitiannya menemukan bahwa secara keseluruhan etnis menunjukkan variabilitas terbesar berkaitan dengan aktivitas keagamaan. Siswa Kaukasia melaporkan paling sedikit menggunakan aktivitas keagamaan dan orang 
Afrika Amerika melaporkan penggunaan aktivitas keagamaan tertinggi. Hasil penelitian menemukan bahwa agama adalah salah satu metode yang paling sering digunakan untuk meningkatkan kebahagiaan. Dengan demikian, agama adalah prediktor kebahagiaan yang sangat kuat. Powers, Cramer, dan Grubka (2007) menyelidiki peran stres kehidupan, integrasi kehidupan spiritual dan komitmen keadilan sosial dalam memprediksi kesejahteraan afektif. Penelitiannya melibatkan 136 mahasiswa sarjana di mana 105 perempuan, 30 laki-laki, 1 tidak teridentifikasi dan 5 lainnya tidak menyelesaikan seluruh survei. Usia rata-rata peserta adalah 18 tahun. Hasil penelitiannya menunjukkan bahwa kehidupan spiritual secara signifikan terkait dengan kesejahteraan afektif.

Sorajjakool, Chilson, Ramirez-Johnson dan Earll (2008) mempelajari peran spiritualitas dan makna di antara para peserta yang menderita depresi berat. Para peserta dirawat di Loma Linda University Behavioral Medicine Centre. Ada 15 peserta, 12 perempuan dan 3 laki-laki. Semua 15 peserta diwawancarai dan berpartisipasi dalam kurikulum terstruktur yang termasuk kelas terapi kelompok harian dan bertemu dengan seorang pendeta selama dua jam seminggu. Mereka menemukan bahwa para peserta berfokus pada tiga tema umum selama studi mereka: spiritualitas, makna dan penerimaan. Sebagian besar peserta menunjukkan bahwa depresi mereka membuat mereka merasa terputus dari spiritualitas mereka. Tetapi mereka mengakui bahwa spiritualitas mereka membantu mereka mengatasi depresi. Sebagian besar peserta dalam penelitian ini memiliki keinginan yang kuat untuk memahami pengalaman mereka dengan depresi, untuk melampirkan tujuan atau maknanya. Penerimaan adalah tema umum ketiga bagi para peserta. Penerimaan datang untuk berdamai dengan depresi dan memiliki rasa penyembuhan.

Snoep (Liesbeth Snoep, 2008) melakukan studi lintas budaya dimana ia menggunakan survei nilai dunia di tiga negara: Amerika Serikat, Belanda dan Denmark bersama dengan 7 langkah laporan diri yang menunjukkan agama. Dia juga melakukan pengukuran yang terdiri dari satu pertanyaan tentang kepuasan hidup. Hasil penelitian menunjukkan bahwa kebahagiaan lebih bergantung pada aspek sosial agama daripada pengalaman pribadi agama. Korelasi dengan partisipasi gereja lebih kuat daripada korelasi dengan doa, meditasi, dan kepercayaan kepada Tuhan. Waktu yang dihabiskan 
bersama orang-orang di gereja adalah prediktor terkuat kebahagiaan orang Amerika Serikat dan menjadi anggota organisasi gereja adalah faktor yang paling penting di Denmark dan Belanda. Studinya menunjukkan bahwa efek agama pada kebahagiaan tidak sama di mana-mana.

Robbins, Francis \& Edwards (2012) melakukan penelitian untuk menguji hubungan antara doa dan kebahagiaan. Penelitiannya melibatkan 131 mahasiswa sarjana dari Wales, di mana ada 71 laki-laki, 60 perempuan, 32\% berusia 18 atau 19 tahun, $43 \%$ berusia $20-21$ tahun dan $25 \%$ berusia di atas 21 tahun. Hasil penelitiannya menemukan korelasi positif yang signifikan antara frekuensi doa dan kebahagiaan. Namun, begitu mereka mengendalikan perbedaan individu dalam kepribadian, korelasi menghilang sepenuhnya. Dengan demikian, tampaknya bahwa doa dan kebahagiaan tidak berhubungan tetapi sebaliknya adalah hasil dari perbedaan individu dalam kepribadian.

Sahraian, Gholami, Javadpour, \& Omidvar (2013) mempelajari hubungan antara religiusitas dan kebahagiaan. Hasil penelitian menunjukan bahwa ada korelasi positif antara sikap dan perilaku agama dan tingkat kebahagiaan. Namun, temuan yang berbeda telah dilaporkan. Tujuan dari penelitian ini adalah untuk menguji hubungan antara religiusitas dan kebahagiaan di antara sekelompok mahasiswa Sarjana Muslim. Hasil penelitian menemukan bahwa skor yang lebih tinggi pada keyakinan agama secara signifikan terkait dengan tingkat kebahagiaan. Hasilnya menegaskan bahwa individu dengan sikap yang lebih religius mengalami lebih banyak kebahagiaan.

Bayani (2005) meneliti hubungan antara agama dan kebahagiaan pada 358 mahasiswa Muslim Iran (165 pria, 193 wanita). Instrumen penelitian yang digunakan adalah Oxford Happiness Inventory, Skala Depresi-Kebahagiaan dan Skala Orientasi Agama. Analisis menegaskan hubungan positif yang signifikan antara agama dan kebahagiaan di antara sampel siswa Muslim Iran. Skor pada Skala Orientasi Agama secara signifikan terkait dengan Oxford Happiness Inventory $(\mathrm{r}=0,34, \mathrm{P}<.001)$, seperti halnya skor dengan Skala Orientasi Agama dan Skala Depresi-Kebahagiaan $(r=0,29, \mathrm{P}$ $<0,001)$. 
Babinčák \& Parkanská (2016) menguji hubungan timbal balik antara indikator religiusitas dan spiritualitas berkaitan dengan kebahagiaan yang dirasakan secara subjektif dan verifikasi kekuatan prediktif dari indikator ini berkenaan dengan kebahagiaan subyektif. Sampel dari peserta penelitian terdiri dari 194 mahasiswa yang berusia 18 hingga 26. Penelitian ini menggunakan 4 alat ukur: The Expressions of Spirituality Inventory-Revised, The Salience dalam Skala komitmen agama, skala Hapinness Subyektif dan The Oxford Happiness Questionnaire. Dengan menggunakan regresi linier hirarkis (bertahap), penelitian menghasilkan 2 dimensi spiritualitas sebagai prediktor signifikan dari kebahagiaan subyektif-kesejahteraan eksistensial dan dimensi experiential/phenomenological. Data demografi dan jenis pengakuan tidak terbukti sebagai prediktor kebahagiaan.

\section{Metode}

\section{Sumber Data}

Pengumpulan data diperoleh dari, Ebsco, Proquest, Dissertation Abstract dan Dissertation Abstract International. Kata kunci yang digunakan adalah "religion", "religiosity", "spiritual”, "prayer" dan happiness". Oleh karena, penelitian ini untuk melakukan analisis dengan menggunakan pendekatan metaanalisis secara kuantitatif, maka data yang digunakan adalah: (a) jumlah Subjek (N), (b) salah satu dari nilai korelasi $\mathrm{r}, \mathrm{F}$, atau $\mathrm{t}$, (c) bila item $\mathrm{b}$ tidak disertakan, maka naskah harus mencantumkan rerata skor (M) dan standar deviasi (SD). Berdasarkan langkah-langkah tersebut diperoleh sejumlah 9 naskah.

\section{Metode Analisis Data}

Analisis data penelitian dilakukan melalui empat tahap: pertama, Manajemen data. Menejemen data dilakukan dengan melakukan pengkodean pada beberapa penelitian yang telah dilakukan mengenai hubungan religiusitas atau keberagamaan dan kebahagiaan. Ada beberapa dimensi yang diukur, dan terkadang ada pula dimensinya yang berbeda antara penelitian yang satu dengan lainnya walaupun nama variabelnya sama, bahkan ada pula sebaliknya variabelnya berbeda tapi maknanya bisa dikategorikan sama. Kedua, pengkodean dilakukan dengan mengkelompokkan variabel 
yang kurang lebih maknanya mendekati berkaitan agama dan kebahagiaan. Ketiga, untuk data yang masih mengandung nilai $\mathrm{F}, \mathrm{t}$, atau dikonversikan terlebih dahulu ke nilai $r$ sehingga siap diperbandingkan. Keempat, dengan mengikuti pendapat Hunter \& Schmidt (1990) bahwa kesalahan sampling ini memberikan dampak tidak terstruktur dan sangat dipengaruhi besarnya sampel dan koreksi kesalahan pengukuran, sehingga dalam penelitian ini selanjutnya menggunakan dua koreksi terhadap data yang diperoleh berupa koreksi kesalahan pengambilan sampel dengan alasan kesalahan pengambilan sampel (sampling error) adalah artefak yang paling banyak mencemari hasil penelitian.

Menurut Sugiyanto (2008) langkah-langkah dalam melakukan koreksi kesalahan pengambilan sampel bisa dilakukan dengan mencari estimasi $r$ populasi, varian $r$ populasi terbobot, varian $r$ populasi kesalahan pengambilan sampel dan estimasi varian $\mathrm{r}$ populasi. Langkah yang ditempuh dalam melakukan koreksi kesalahan pengukuran dengan menentukan kesalahan pengukuran pada salah satu variabel atau dua variabel sekaligus, mencari reliabilitas intstrumen, koreksi kesalahan pengukuran $\mathrm{x}$ dan $\mathrm{y}$, rerata kesalahan pengukuran pada $\mathrm{x}$ dan $\mathrm{y}$ sampai akhirnya estimasi $\mathrm{r}$ populasi.

\section{Hasil}

Hasil Analisis data tentang hubungan antara agama dengan kebahagiaan, menghasilkan data yang memenuhi persyaratan untuk dilakukan meta-analisis (tabel 1).

Tabel 1. Tabulasi Data Penelitian yang memenuhi syarat untuk dianalisis

\begin{tabular}{|c|c|c|c|c|c|c|}
\hline \multirow[t]{2}{*}{ Penelitian } & Variabe & \multicolumn{2}{|c|}{ Variabe } & \multirow[b]{2}{*}{$\mathbf{x y}$} & & \\
\hline & 1 Independen & 1 Dependen & & & & \\
\hline Abdel- & Religios & & & & & \\
\hline Khalek, A.M (2010) & ity & ess & 24 & .21 & .84 & .60 \\
\hline Francis, L.J., & Attitude & & & & & \\
\hline $\begin{array}{l}\text { Elken A.\& Robbis, M. } \\
\text { (2012) }\end{array}$ & $\begin{array}{l}\text { toward } \\
\text { Christianity }\end{array}$ & ess & 50 & .12 & .98 & .89 \\
\hline Pena, $\quad \mathrm{V}$ & Religios & ess & 9 & .11 & .90 & .94 \\
\hline
\end{tabular}




\begin{tabular}{lrrrrrr}
\multicolumn{3}{c}{ Sahraian, } & Religiou & Happin & & \\
A., Gholami, A., s belief & & ess & & 71 & .25 \\
Javadpour, A \& & & & & & &
\end{tabular}

Omidvar, B. (2013)

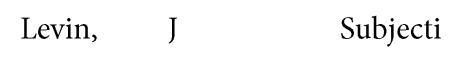
ve religiosity es

Happin

ess

(2014)

Levin, tural Beliefs

ess

Happin

$91 \quad .18$

(2014)

Levin, J Certaint y of God beliefs

ess

Happin

$91 \quad .07$

$$
\text { Levin, J Prayer }
$$

ess

Happin

$91 \quad .13$

Levin,

Synagog

Happin ess

$91 \quad .11$

Agbaria, Q.

$$
\text { ue attendance }
$$

Happin

ess

$25 \quad .48$

.93

Francis, L.J.,

1 Yablon, Y.B. \& ity

Religios

ess

Happin Robbins, M. (2014)

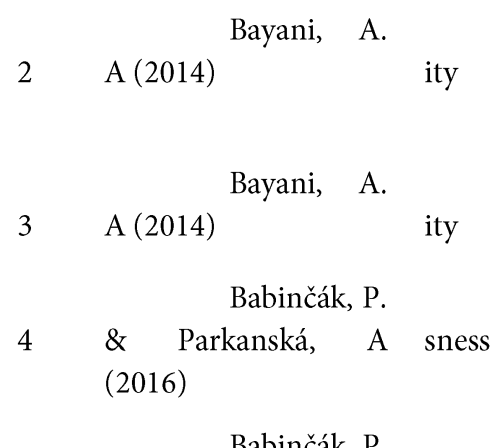

Religios

Oxford
Happiness

58

.34

$.91 \quad .8$

Depress
ion-Happiness

$\begin{array}{llll}58 & .29 & .91 & .93\end{array}$

Religiou

ve Hapinness

$\begin{array}{llll}94 & .09 & .91 & .79\end{array}$

Religiou

Oxford

5 \& Parkanská, A sness (2016)

Berikut ini, hasil koreksi kesalahan pengambilan sampel dan kesalahan pengukuran yang menguji hubungan antara agama dan kebahagiaan. 


\section{Koreksi kesalahan pengambilan sampel untuk menguji hubungan antara agama dan kebahagiaan.}

Analisis perhitungan koreksi terhadap kesalahan pengambilan sampel didapatkan 15 studi, dengan melibatkan total subjek 7272 orang. Berikut ini hasil rangkuman data perhitungan koreksi kesalahan pengambilan sampel hubungan antara agama dengan kebahagiaan. Berdasarkan hasil koreksi terhadap kesalahan pengambilan sample diperoleh estimasi $\mathrm{r}$ populasi (rerata $\mathrm{r}$ ) $=0,174$ dengan varian korelasi populasi terbobot $\mathrm{Sr}^{2}=0,00813$, varian korelasi kesalahan pengambilan sampel $\mathrm{Se}^{2}=0,00233334$ dan estimasi varian korelasi populasi $\sigma \rho r^{2}=0,00579$. Adapun dampak kesalahan pengambilan sampel sebesar 40,29\%. Hasil perhitungan koreksi artefak kesalahan pengambilan sampel hubungan antara agama dengan kebahagiaan dapat dilihat pada Tabel 2.

Tabel 2. Rangkuman data perhitungan koreksi kesalahan pengambilan sampel hubungan antara agama dengan kebahagiaan.

\begin{tabular}{ll}
\hline Keterangan & Hasil \\
\hline Jumlah Sampel $(\mathrm{N})$ & 7272 \\
Total r & 2.93 \\
estimasi r populasi atau rerata $\mathrm{r}(\hat{\mathrm{r}})$ & 0.174 \\
varian korelasi populasi terbobot $\left(\mathrm{Sr}^{2}\right)$ & 0.00813 \\
varian korelasi kesalahan pengambilan sampel $\left(\mathrm{Se}^{2}\right)$ & 0.00233338 \\
estimasi varian korelasi populasi $\left(\sigma \rho r^{2}\right)$ & 0.00579 \\
dampak kesalahan pengambilan sampel sebesar & $40.29 \%$ \\
\hline
\end{tabular}

\section{Koreksi kesalahan pengukuran untuk menguji hubungan antara agama dengan kebahagiaan}

Hasil rincian koreksi terhadap artefak pengukuran, diperoleh rerata kesalahan pengukuran A sebesar 0,242735283, sedangkan estimasi korelasi populasi ( $\rho$ ) sebesar 0,715834339, jumlah koefisien kuadrat variasi (V) sebesar 1,950092569, varian yang mengacu variasi artefak $\left(\sigma^{2} 2\right)$ sebesar 0,058877058, varians korelasi populasi sesungguhnya Var $(\rho)$ sebesar -0,900970747, dan interval kepercayaan ( $\mathrm{r} \rho$ sebesar 0,06076. Adapun dampak variasi reliabilitas 96,90\%. Hasil perhitungan koreksi artefak 
kesalahan pengukuran untuk menguji hubungan antara agama dengan kebahagiaan, dapat di lihat pada Tabel 3.

Tabel 3. Rangkuman data perhitungan koreksi artefak kesalahan pengukuran untuk menguji hubungan antara agama dengan kebahagiaan.

\begin{tabular}{ll}
\hline Keterangan & Hasil \\
\hline Jumlah Sampel (N) & 7272 \\
Jumlah Studi & 15 \\
rerata kesalahan pengukuran (A) & 0.242735283 \\
estimasi r populasi atau rerata $\mathrm{r}(\hat{\mathrm{r}})$ & 0.715834339 \\
varian korelasi populasi terbobot $\left(\mathrm{Sr}^{2}\right)$ & 1.950092569 \\
varian korelasi kesalahan pengambilan sampel $\left(\mathrm{Se}^{2}\right)$ & 0.058877058 \\
estimasi varian korelasi populasi $\left(\left(\sigma \rho{ }^{2}\right)\right.$ & -0.900970747 \\
dampak kesalahan pengambilan sampel sebesar & 0.06076 \\
estimasi r populasi atau rerata $\mathrm{r}(\hat{\mathrm{r}})$ & $96.90 \%$ \\
\hline
\end{tabular}

Berdasarkan data di atas, total $r$ didapatkan sebesar 2, 93 yang diperkirakan bahwa korelasi rata-rata untuk populasi penelitian adalah $r=0,174$. Sampel ini representatif karena hanya 40,29\% dari varians korelasi disebabkan oleh kesalahan sampling dan dampak variasi reliabilitas adalah 96,90\%. Dengan kata lain, kesalahan pengukuran masih dalam kisaran kepercayaan. Analisis ini mengarah pada kesimpulan bahwa ada korelasi antara agama dan kebahagiaan. Hasil yang diperoleh oleh penelitian ini menunjukkan korelasi yang signifikan antara agama dan kebahagiaan atau spiritualitas dan kebahagiaan.

\section{Pembahasan}

Beragama adalah komitmen atau pengabdian kepada ajaran agama tertentu. Kegiatan ritual termasuk berdoa, membaca kitab suci, menghadiri persembahyangan di tempat ibadah, menyembah Tuhan atau dewa tertentu, mengikuti posisi doktrinal tertentu, dan mengidentifikasi diri sebagai bagian dari komunitas agama tertentu. Agama kadang-kadang digunakan dengan motif praktis seperti untuk memberikan rasa keamanan, kenyamanan, status atau dukungan sosial, sementara yang lain fokus pada agama untuk menjalani kehidupan yang tidak mementingkan diri dan penuh kasih 
(Van Dierendonck \& Mohan, 2006). Steger dan Frazier (Steger \& Frazier, 2005) menyatakan bahwa agama memberi orang kesempatan untuk menemukan makna dalam hidup mereka karena orang memiliki kebutuhan untuk percaya bahwa hidup mereka penting.

Glatzer (2000) menyatakan bahwa kebahagiaan dapat didefinisikan dalam banyak hal tetapi paling sering identik dengan kesejahteraan subjektif (Subjectif wellbeing). Kesejahteraan subjektif dapat digambarkan sebagai kebahagiaan keseluruhan dengan kehidupan secara keseluruhan, tetapi kebahagiaan keseluruhan sangat tergantung pada kepuasan dalam berbagai domain kehidupan. Demikian ini karena kebahagiaan secara keseluruhan dipengaruhi oleh begitu banyak faktor sehingga pencarian determinannya berlangsung selamanya. Kesejahteraan subjektif individu ditentukan melalui berbagai cara. Misalnya, seseorang dapat mengukur kehidupan seseorang dalam segmen besar seperti pekerjaan atau pernikahan, atau dalam kulminasi segmen kecil seperti mampu mengingat kenangan masa kecil. Sebagian besar pendekatan yang diidentifikasi dalam evaluasi kesejahteraan subjektif bervariasi dalam berbagai posisi. Salah satu pendekatan memandang kesejahteraan subjektif sebagai evaluasi keseluruhan dari kehidupan seseorang termasuk semua aspeknya. Pendekatan lain memandang kesejahteraan subjektif sebagai puncak pengalaman emosional individu di mana emosi diukur selama periode waktu yang berbeda dalam kehidupan seseorang (Kim prieto, Diener, Tamir, Scollon, \& Diener, 2005).

Penelitian ini adalah verifikasi hubungan timbal balik antara agama dan kebahagiaan, tetapi pendekatan psikologis mengandaikan bahwa ilmuwan sosial dapat secara akurat mendefinisikan kebahagiaan. Namun, pengukuran kebahagiaan individu, kepuasan hidup, dan kesejahteraan subjektif mungkin benar-benar mencerminkan nilai, budaya, dan pandangan keagamaan para ilmuwan itu sendiri. Akibatnya, kesimpulan yang dicapai dalam studi kebahagiaan dan kesejahteraan subjektif dalam psikologi saat ini didasarkan pada asumsi yang mungkin didasarkan pada pandangan dunia sekuler atau etnosentris dari perkembangan manusia sebagai pencapaian pengaruh positif dan pencapaian tujuan pribadi. 
Hasil meta-analisis ini sebagai hasil penelitian meta-analisis lainnya memiliki beberapa keterbatasan. Pertama, hasil penelitian meta analisis didasarkan pada korelasi alami dan, karenanya, tidak dapat menjamin kesimpulan yang kuat. Kedua, hasil penelitian meta-analisis sering dibatasi oleh kualitas penelitian utama. Ketiga, pengaruh budaya, termasuk berbagai latar belakang etnis yang diabaikan. Variabel agama dan kebahagiaan di negara Indonesia dimungkinkan mempunyai pengertian dan makna yang berbeda dengan di negara-negara Barat, di mana teori dan konstruk di kembangkan. Oleh karenanya, ada banyak pertimbangan ketika disesuaikan dengan kondisi di Indonesia.

Sebuah penelitian tidak dapat dipercayai dengan penuh karena adanya artefak atau kesalahan yang dibuat oleh peneliti. Penelitian masa depan diharapkan untuk memasukkan kriteria yang lebih ketat untuk memastikan bahwa beberapa faktor lain dapat dimasukkan seperti dengan melihat spesifikasi alat ukur yang digunakan misalnya mengenai identitas agama, budaya atau kriteria diperluas untuk menguji pengaruhnya terhadap alat pengukuran kebahagiaan dengan variabel yang lebih spesifik. Demikian pula, hasil penelitian ini dapat menjadi petunjuk yang lebih spesifik untuk penelitian lebih lanjut bahwa agama mempengaruhi kebahagiaan.

\section{Simpulan}

Banyak teori dan penelitian yang mencoba menjelaskan, mengarahkan dan memprediksi berbagai hal yang berkaitan dengan kebahagiaan dan salah satunya adalah faktor agama. Riset tentang agama yang dikaitkan dengan kebahagiaan telah banyak dilakukan. Demikian ini di karenakan kebahagiaan adalah aspek yang dicari sepanjang kehidupan manusia. Tujuan artikel ini adalah untuk melihat apakah agama dapat menentukan kebahagiaan. Hasil artikel ini menunjukkan bahwa, total $r$ didapatkan sebesar 2, 93 yang diperkirakan bahwa korelasi rata-rata untuk populasi penelitian adalah $r=0,174$. Sampel ini representatif karena hanya 40,29\% dari varians korelasi disebabkan oleh kesalahan sampling dan dampak variasi reliabilitas adalah 96,90\%. Hasil analisis ini mengarah pada kesimpulan bahwa ada hubungan yang signifikan antara agama dan kebahagiaan. 


\section{Referensi}

Abdel, K., \& Ahmed, M. (2006). Happiness, Health, and Religiousity: Signficant Relations. Mental Health, Religion on Culture, 9(1), 85-97. http://doi.org/https://doi.org/10.1080/13694670500040625

Abercrombie, N., Hill, S. Turner, B. S. (2006). Collins Dictionary of Sociology (Fifth Edit). London: Penguin Books.

Ali, A., \& Muhdho, A. Z. (1996). Kamus Kontemporer Arab Indonesia. Yogyakarta: Multi Karya Grafia.

Argyle, M., \& Hills, P. (2000). Religious Experiences and Their Relations with Happiness and Personality. The International Journal for the Psychology of Religion, 70(3), 157-172.

Babincak, P., \& Parkanska, A. (2016). Religiosity and Spirituality as Predictors of Subjectively Perceived Happiness in University Students in Slovakia. IAFOR Journal of Psychology on The Bahavoral Science, 2(1), 33-43.

Barkan, S. E., \& Greenwood, S. F. (2003). Religious Attendance and Subjective WellBeing among Older Americans: Evidence from the General Social Survey. Review of Religious Research, 45, 116-129.

Bayani, A. (2005). The Relationship Between Religousity and Happiness among Students in an Iranian University. Pertanika J. Soc. Scie on Hum, 22(3), 709-716.

Diener, E., Lucas, R. E., \& Oishi, S. (2005). Subjective Well-Being: The Science of Happiness and Life Satisfaction. New York: Oxford University Press. Inc.

Diener, E., \& M.E.P, S. (2002). Very Happy People. Pychological Science, 13, 80-83.

Eddington, N., \& Shuman, R. (2008). Subjective Well-Being (Happiness). California: Continuing Psychology Educaion Inc.

Ellison, C. ., \& George, L. . (1994). Religious Involment, Social Ties, and Social Support in a Southeastern Community. Journal for The Scientific Study of Religion, 33, 4661 .

Faiver, C., Ingersoll, R. E., O’Brien, E., \& McNally, C. (2001). Explorations in Counseling and Spiritaulity. Belmont, CA: Wadsworth/Thomson Learning.

Francis, L. ., Elken, A., \& Robbins, M. (2012). The Affective Dimension of REligion and PErsonal happiness Among Students in Estonia. Journal of REsearch on Christian Education, 21, 84-90. 
French, S., \& Joseph, S. (1999). Religiosity and its association with happiness, purpose in life, and self-actualisation. Mental Health, Religion \& Culture, 2(2), 117-120. http://doi.org/10.1080/13674679908406340

Gabriellle, R. (2008). Orientations to Happiness: Do They Make a Difference in a Student's Educational Life. American Secondary Education, 36(2), 88-101.

Ghufron, M. ., \& Risnawati, R. (2010). Teori-teori Psikologi. Yogyakarta: Ar-Ruz Media.

Kahmad, D. (2002). Sosiologi Agama. Bandung: PT. Remaja Rosdakarya.

Kim prieto, C., Diener, E., Tamir, M., Scollon, C. N., \& Diener, M. (2005). Integrating the diverse definitions of happiness: A time-sequential framework of subjective well-being. Journal of Happiness Studies, 6, 261-300. http://doi.org/10.1007/s10902005-7226-8

Liesbeth Snoep. (2008). Religiousness and happiness in three nations: a research note. Journal of Happiness Studies, 9(2), 207-211. http://doi.org/10.1007/s10902-0079045-6

Malpere, S. (2010). The Correlation Between Religion, Spirituality and Happiness, Electronic These and Dissertions. Kean University: New Jersey.

Masse, R. A. (2016). Wanita dan Pembinaan Moral (Suatu Analisis Filsafat Akhlak. AlMaiyyah, 9(2), 247-267.

Mattis, J. ., \& Jagers, R. . (2001). Ilmu Perbandingan agama. Journal of Community Psychology, 29(5), 519-539.

Miller, W. ., \& Thoresen, C. . (2003). Spirituality, Religion and Health: An Emerging Research Field. American Psychologist, 55(1), 24-35.

Peterson, C., Park, N., \& Seligman, M. E. . (2005). Orientations to Happiness and Life Satisfaction: The Full Life Versus The Empty Life. Journal of Happiness Studies, 5, $25-41$.

Powers, D. ., Cramer, R. ., \& Grubka, J. . (2007). Spirituality, Life Stress and Affective Well-Being. Journal of Psychology and Theology, 55(3), 235-243.

Reitsma, J., Scheepers, P., \& Jansen, J. (2007). Convergent and Discriminate Validity of Religiosity Measures among Church Members and Non-members. Personality and Individual Differences, 42(7), 1415-1426.

Sahraian, A., Gholami, A., Javadpour, A., \& Omidvar, B. (2013). Prayer, Personality and Happiness: A Study among Undergraduate Students in Wales. Journal of Religion and Health, 52(2), 450-453. 
http://doi.org/https://doi.org/10.1080/13674670701702548

Sappington, A. A., \& Baker, J. (1995). Refining Religious Belief-Behavior Relations. The International Journal for the Psychology of Religion, 5(1), 39-48.

http://doi.org/10.1207/s15327582ijpr0501_5

Shaeful RS, A. (2011). Rahasia Kebahagiaan. Jaqfi: Jurnal Aqidah dan Filsafat Islam, (3), 97-105.

Sorajjakool, S., Aja, V., Chilson, B., Ramirez-Johnson, J., \& Earll, A. (2008).

Disconnection, Depression and Spirituality: A Study of The Role of Spirituality and Meaning in the Lives of Individuals with Severe Depression. Pastoral Psychology, 56, 521-532.

Steger, M. ., \& Frazier, P. (2005). Meaning in Life: One Link in Chain from Religiousness to Well-Being. Journal of Counseling Psychology, 52(4), 574-582.

Tkach, C., \& Lyubomirsky, S. (2006). How do People Pursue Happiness? Relating

Personality, Happiness-Incresing Strategies and Well-Being. Journal of Happiness Studies, 7, 183-225.

Utami, M. S. (2012). Religiusitas, Koping Religius, dan Kesejahteraan Subjektif. Psikologi, 39(1), 46-66. http://doi.org/10.1016/j.jpainsymman.2006.01.007

Utami, T. N., \& Nuraini. (2016). Analisis Spiritual Value, Stress Kerja Pekerja Muslim Sektor Formal Kota Medan. Jumantik, 1(1), 1-24.

Van Dierendonck, D., \& Mohan, K. (2006). Some Thoughts on Spirituality and Eudaimonic Well-Being. Mental Health, Religion on Culture, 9(3), 227-238.

Veenhoven, R. (2009). How do we Asses how Happy we are? Tenest, Implications and Tenability of Three Theories. In Happiness, Economics and Politics: Towards a Multidiscplinary Approach. Cheltenham, UK: Edward Elger Publishers.

W, G. (2000). Happiness: Classic Theory in The Light of Current Research. Journal of Happiness Studies 1, 1, 501-511.

Wahyuningsih, H. (2008). Religiusitas, spiritualitas, dan kesehatan mental: meta analisis. Psikologika: Jurnal Pemikiran dan Penelitian Psikologi, 13(25), 61-72. 
Halaman ini bukan sengaja untuk dikosongkan 